\title{
Environmental Perception of 5th Year Elementary School Students through Cultivation and Phenotypic Plasticity of Plants
}

\author{
Paula Cardoso Ferah'1, Gabriel Araujo Sodré1, Helena Roland Rodrigues Lima1, \\ Luana Vieira Campos ${ }^{1}$, Sueli Soares de Sá Mancebo ${ }^{2}$, Helena Carla Castro ${ }^{1,2}$, \\ Selma Ribeiro de Paiva ${ }^{3}$, Neuza Rejane Wille Lima1,2* \\ ${ }^{1}$ ProPetBiofronteiras, Instituto de Biologia, Universidade Federal Fluminense, Niterói, Brasil \\ ${ }^{2}$ Programa de Pós-Graduação em Ciências e Biotecnologia, Universidade Federal Fluminense, Niterói, Brasil \\ ${ }^{3}$ Programa de Pós-Graduação em Ciências Aplicadas a Produtos para a Saúde, Universidade Federal Fluminense, Niterói, Brasil \\ Email: ^rejane_lima@id.uff.br
}

How to cite this paper: Ferah, P. C., Sodré, G. A., Lima, H. R. R., Campos, L. V., de Sá Mancebo, S. S., Castro, H. C., de Paiva, S. R., \& Lima, N. R. W. (2019). Environmental Perception of 5th Year Elementary School Students through Cultivation and Phenotypic Plasticity of Plants. Creative Education, 10, 1685-1701.

https://doi.org/10.4236/ce.2019.107120

Received: June 19, 2019

Accepted: July 26, 2019

Published: July 29, 2019

Copyright $\odot 2019$ by author(s) and Scientific Research Publishing Inc. This work is licensed under the Creative Commons Attribution International License (CC BY 4.0).

http://creativecommons.org/licenses/by/4.0/

\begin{abstract}
The study of children's environmental perception is an essential tool for understanding the behavior and planning actions that provide awareness and development of their ethical position towards the environment they live in. The objective of this study was to evaluate the opinion of students of the 5th year of Elementary School about the concepts related to the importance of the environmental condition to plants. The activities involved 26 children from nine to eleven years old. They made: 1 ) a comparison between Boldo Mirim (Plectranthus neochilus) and Boldo Brasileiro (P. barbatus); 2) an experiment with Boldo Brasileiro and observed the development of this plant in relation to two nutritional conditions of the soil and four solar intensities. It was possible to identify the children's perception of plant characteristics and the results of the experiments performed through the measurements they made on the plants, the observation of the experiment carried out, their questionnaire replies, their reports, and their drawings. This strategy contributes to children's knowledge of abiotic (soil, light) and biotic factors (root production, and plant growth) related to plant phenotipic plasticity in response to different environmental conditions. The activities performed helped the children to construct environmental perception and deconstruct the botanic blindness that affects most people since an early age.
\end{abstract}

\section{Keywords}

Drawings, Planting, Questionnaire, Report, Soil, Sun Light 


\section{Introduction}

Concern about the environment is evident in the face of the degration and consequent loss of biodiversity and natural resources. In this sense, it is imperative to promote the awareness of the population in order to maintain these precious assets. However, to conserve it is necessary to know and we often do not realize what is around us.

\subsection{Environmental Perception}

Popular knowledge that passes from one generation to another range from facts about natural phenomena such as rainfall regime, the cycle of tides, the growth of animals and vegetables that belong to the food chain, and the pharmacological importance of some plants.

However, the environmental perception of nature cycles has been distorted since the 1950s due to great urban growth and technological development. People who live in such environments tend to lose their ability to perceive the cycles of nature, losing the opportunity to construct mental images of the components of nature (Ribeiro, 2003; Marczwski, 2006; Pasa, 2011).

In reality, everyone will react differently in relation to the actions on the environment in which they live. The responses or manifestations to the environment reflect the actions of individuals or collective perceptions (Rodrigues et al., 2012).

There is an intimate relationship between environmental perception and environmental education, because it is through perception that we identify the main needs and expectations of one community. Thus, knowledge about the relation of the individuals with their environment might permit the development of effective tools to perform a quality environmental education (Marczwski, 2006).

Through environmental education, students can feel and understand the importance of the natural resources existing on the planet and the relationship with all living beings when they participate in activities that involve the observations of animals and plants. In addition, the results of experiments necessary to understand nature (Adams, 2009), such as phenotypic plasticity of plants due to environmental variation, will assist this understanding (Sodré et al., 2018; Sodré et al., 2019).

\subsection{Phenotypic Plasticity of Plants}

Phenotypic plasticity is classically defined as the change in genotypic expression as a function of the environment (Scheiner, 1993). This definition can be better understood following observation of the capacity of a given living being to present different morphological, physiological, behavioral and/or phenological characteristics in response to changes in environmental conditions (Futuyma, 2006; Lima et al., 2017a).

In the present study, we selected two species of the genus Plectranthus L'Héritier: 
Plectranthus neochilus Schltr. (known as Boldo Mirim) and P. barbatus Andrews (known as Boldo Brasileiro) (Lukhoba et al., 2006) that expresses phenotypic plasticity (Rosal et al., 2011; Lima, 2017; Sodré et al., 2018; Lima, 2019; Sodré et al., 2019).

These two plants originate in Africa and commonly grown at home and in medicinal gardens throughout the World. They are small shrubs, easily cultivated in pots. They are rich in essential oils and have importance in folk medicine to treat digestive and respiratory disorders, infections and fever (Costa, 2006; Lukhoba et al., 2006; Rosal, 2008, Rosal et al., 2011; Lima et al., 2017a, b; Sodré et al., 2018).

The two species of Plectranthus were chosen to establish comparisons of plant characteristics. The Boldo Mirim expresses phenotypic plasticity in a short period of time (Rosal et al., 2011; Lima et al., 2017a; Sodré et al., 2018). The Boldo Brasileiro was used to carry out experiments to demonstrate the phenomenon of phenotypic plasticity, based on strategies applied by other studies that used Boldo Mirim (Rosal, 2008; Rosal et al., 2011; Lima, 2017; Lima et al., 2017a, 2017b; Lima, 2019; Sodré et al., 2018).

\subsection{Botanic Blindness}

According to Salatino and Buckeridge (2016), nowadays, most people who go through elementary and secondary education see botany as an uninteresting subject. Plant Biology usually passes as a tedious and arid subject, better left in the background.

These authors stated: If we show someone a typical photo of an African savannah in which there are trees, shrubs and giraffes and ask them what they see in this photo, the answer would be: Giraffes!!!! The probability of the person mentioning the plants present in the photo, would be minimal or zero. This is "botanical blindness", a term introduced by Wandersee and Schussler in 1999. Therefore, it is relevant throughout childhood to stimulate a positive feeling about plants, recognizing the primordial importance of these organisms not only in the food chain and in the treatment of diseases, but also for environmental equilibrium (Fančovičová \& Prokop, 2011; Çil, 2016).

Laboratory experiments and observations of the nature of plants in orchards and crops awaken children's curiosity. The use of plants in laboratory classes has several advantages, since they are widely available and easy to handle (Salatino \& Buckeridge, 2016). However, Fančovičová \& Prokop (2011) reported that participants' attitudes towards plants and knowledge of their significantly increased after outdoor activities. Likewise, Dyg \& Wistoft (2018) described the importance of outdoor activities for the welfare of children and students from kindergarten up to ninth grade.

The question that generated the present study was: Could the comparative observation between two species of Plectranthus know as Boldo Mirim and Boldo Brasileiro associated to the experimental cultivation of one species ( $P$. barbatus) stimulate, among the children, the construction of knowledge about the in- 
fluence of the environment on the expression of phenotipic plasticity?

\subsection{Why to Study Plants in a Class at 5th Year of Elementary School?}

The children from the 5th year of the elementary school named Colégio Universitário Geraldo Reis (COLUNI-Geraldo Reis University School) attend an environmental education class that addresses issues of environmental perception. This school belongs to the Fluminense Federal University.

The teacher responsible for this class asked us two questions: How can the children develop perception about environmental factors that are important to plants? How to deconstruct the botanical blindness that commonly affects them?

Experiments using a plant of the genus Plectranthus were useful for demonstrating for COLUNI's 2nd year of the elementary school student the ability of plants to respond to environmental variables and express phenotypic plasticity (Sodré et al., 2018). Therefore, we adapted the strategies developed by this study to answer the questions of the teacher.

Thus, the objective of this study was to evaluate in a class at 5th year of Elementary School children the construction of concepts about the importance of the environment to plants.

\section{Material and Methods}

The study was registered in the SIGPROJ platform (http://sigproj.ufrj.br/"Plasticidade Fenotípica de Boldosdo Gênero Plectranthus L'HerItierem diferentes ambientes: ensino, pesquisa e extensão" ["Phenotypic Plasticity of Boldos of the genus Plectranthus L'HerItier in Different Environments: teaching, research and extension"] (protocol number 279383.1347.512114.31102017).

All the activities and the dissemination of materials and images produced by the students were granted through a signed consent by the parents or guardians of the children.

These activities were proposed through the Tutorial Education Program and supported by the Federal Fluminense University (Castro et al., 2014) and the Science and Biotechnology postgraduate course of the same university.

The study was carried out during the first half of 2018. It involved 26 children of 5th-year elementary school and the teacher who teaches the discipline of environmental education at COLUNI.

The class consisted of 12 boys and 14 girls ranging from nine to eleven years old. During all the activities, they were divided into two mixed groups of $13 \mathrm{stu}-$ dents each.

\subsection{Experimental Desing}

The study was conducted in three steps:

- Day 1-1) cuttings of Boldo Brasileiro were produced to be cultivated in two types of soil during 30 days in full light; 2 ) comparative analysis of the cha- 
racteristics of the Brazilian Boldo (Plectranthus barbatus) and Boldo Mirim ( $P$. neochilus) branches were evaluated.

- Day 2-the development of roots in the Boldo Brasileiro's cuttings-seedling formation-and transference of the pots with the seedlings to the four greenhouses.

- Day 3-evaluating the expression of the phenotypic plasticity of the Boldo Brasileiro after 30 days with different soil nutrition as well as sunlight intensity.

First of all, a meeting was held with each group of children to discuss the importance of plants to the environment, food source and to treat diseases.

In sequence, all the materials needed for cultivation were distributed: the Boldo Brasileiro stakes, eight plastic pots of eight liters each, plastic blades, a solution that stimulates root formation, and three types of soil obtained commercially: 1) earthworm humus + bovine manure; 2) vegetable compost; 3 ) poultry manure.

\subsection{Planting of Boldo Brasileiro Cuttings}

Basically two types of soils were prepared: Type 1 was already commercially prepared in the proportion 1:1 and type 2 was a mixture of three parts of the vegetable compost with one part of poultry manure $(3: 1)$.

The children prepared the type 2 soil. They knew that this latter soil had higher concentrations of the micronutrients compared to soil type 1, especially, phosphorus, and manganese due to the poultry manure (Sodré et al., 2018).

The children were instructed to add soil 1 to four pots and soil 2 to the other four pots. Subsequently, each child received a $10 \mathrm{~cm}$ cutting of Boldo Brasileiro. The children cut their cutting below the third knot from the apex. They put their cuttings for 10 minutes in a solution that stimulates root development and planted them in the eight pots. The pots were transferred to the outside area of the school to receive full sunlight for 30 days.

At the end of the activity, the children received new cuttings of the Boldo Brasileiro and Boldo Mirim. They answered a questionnaire with comparative questions about the morphometric and odor characteristics of these plants (Table 1).

At the end of the activity, the children drew on what they learned from the activities carried out that day.

After 30 days of cultivation, the children observed the results of the experiments. On that day, they unearthed the plants and observed the development of roots, that is, the transformation of cuttings into seedlings.

Table 1. Mark the answers to the five questions about plants with X. Moreover answer with a phrase the question number 5 .

Questions

1) Which Boldo has the largest leaves? ( ) Boldo Brasileiro ( ) Boldo Mirim

2) Which Boldo has the most scented leaves? ( ) Boldo Brasileiro ( ) Boldo Mirim

3) Which is the Boldo that has the roughest leaves? ( ) Boldo Brasileiro ( ) Boldo Mirim

4) Which is the Boldo that has the greenest leaves? ( ) Boldo Brasileiro ( ) Boldo Mirim

5) Did you like to set up the experiment? ( ) Yes ( ) No-Why? 
Soon after replanting of the seedling, the children replaced the pots in four greenhouses built with expanded polystyrene (EPS Isopor ${ }^{\circledR}$ ) boxes.

These boxes had the sides partially withdrawn for $100 \%$ light input. Three of them were covered with SOMBRITE (90, 70 and 50) type screens to promote three solar intensities $(10 \%, 30 \%, 50 \%)$. The fouth box was not covered with SOMBRITE to promote $100 \%$ solar intensity.

These boxes with pots were conditioned in the outer area of the school for 30 days. At the end of this activity, the children wrote texts about their experiences.

The children and the teacher of the Environmental Education discipline were responsible for watering the plants twice a week during the 30 days of the experiments. At the end of the experiment, the pots with the plants were brought by them to the laboratory to measure the plants' morphology.

\subsection{Biometry of Plant}

The children received metric tapes to measure the size of the Boldo Brasileiro branches. In addition, the children counted the leaves of each branch. Each child noted the results in individual tables and wrote essays on the differentiated characteristics (phenotypic plasticity) of the plants that were grown in the pots inside the four boxes. After these analyses, the children made the second drawings.

To conclude the activities, a discussion was held about the importance of environmental conditions in the differentiated expression of plant characteristics and their importance to the human and other animals, as a source of medicines to treat health and as a food source or equilibrium in the world climate.

The results obtained were compared through tables and graphs and significance of the differences between the elements contained in the results were tested by two non-parametric: Kruskall-Wallis $(H)$ and Mann-Whitney $(U)$ statistical tests.

Contents reported in the 26 texts written by children after observing the transformation of the stalks into seedlings were analyzed following analysis of content.

\subsection{Soil Chemical Characteristics}

A portion with $500 \mathrm{~g}$ of each of the two substrate types used in the experiments were sent to the Water, Soil and Plant Laboratory (LASP) that belongs to the Brazilian Agricultural Research Corporation's (EMBRAPA) to determine the concentrations of 10 chemical elements (C, Ca, Cu, Fe, K, Mg, Mn, N, P, Zn) that are relevant to the plant growth.

The $\mathrm{Ca}, \mathrm{Cu}, \mathrm{Fe}, \mathrm{Mg}, \mathrm{Mn}, \mathrm{P}, \mathrm{Zn}$ chemical elements were determined by flame atomic absorption spectrophotometry (FAAS) techniques. The $\mathrm{K}$ was digested in a microwave and analyzed in a flame photometer. The $\mathrm{N}$ was determined through analysis in a block digester and Kjeldahl distiller. The percentage of total organic carbon (C-CHN) was determined by dry combustion in a PerKin Elmer 2400 CHNS elemental analyzer. All the analyses followed methods de- 
scribed by Teixeira et al. (2017).

\section{Results}

\subsection{The Comparison between Plants}

The children realized the differences between the Boldo Brasileiro and Boldo Mirim, especially the leaf size, smell, and color (Table 2).

The question "Did you like to like the experiment? Why?" was answered by the 26 children. Among them, 22 children liked the experiment and reported that it was a new experience, that they liked science, had joy in tinkering with the plants and watering them. Only four children responded that they did not like the experiment and said that the smell of the soil was bad, in the case the soil composed of the chicken manure.

During the second meeting (Day 2), the children observed the root development and wrote about the activities related to the replanted Boldo's seedlings and transport of the pots to the boxes.

The contents described in the 26 texts written by children after observing the transformation of the stalks into seedlings analysed (Figure 1). The descriptions of the planting conditions $(n=16)$ and the expression of plant's characteristics $(\mathrm{n}=20)$ were the most cited in the children reports. Moreover, seven reports related that the activities developed were new for them. The importance of plants to the nature and to our health was cited in six reports.

\subsection{Analyses of Soils}

Analyzes of soil composition revealed that the compound of earthworm humus + bovine manure presented a double of the percentage of carbon when compared to the soil containing plant compounds and poultry manure. As expected, these results confirm that soil type 1 contained more micronutrients than soil type 2, as observed by Sodré et al. (2018).

Table 2. Responses pointed out by the children about the characteristics of the two species of Plectranthus known as Boldo Brasileiro ( $P$. barbatus) and Boldo Mirim ( $P$. neochilus).

\begin{tabular}{|c|c|c|c|}
\hline Questions & Groups $(n=13)$ & Plant selected & \\
\hline & & Boldo Brasileiro & Boldo Mirim \\
\hline 1) Which Boldo has the & A & 13 & 0 \\
\hline largest leaves? & $\mathrm{B}$ & 13 & 0 \\
\hline 2) Which Boldo has the & A & 11 & 2 \\
\hline most scented leaves? & $\mathrm{B}$ & 9 & 4 \\
\hline 3) Which is the Boldo that & A & 8 & 5 \\
\hline has the roughest leaves? & $\mathrm{B}$ & 8 & 5 \\
\hline 4) Which is the Boldo that has & A & 9 & 4 \\
\hline the greenest leaves? & $\mathrm{B}$ & 11 & 2 \\
\hline
\end{tabular}




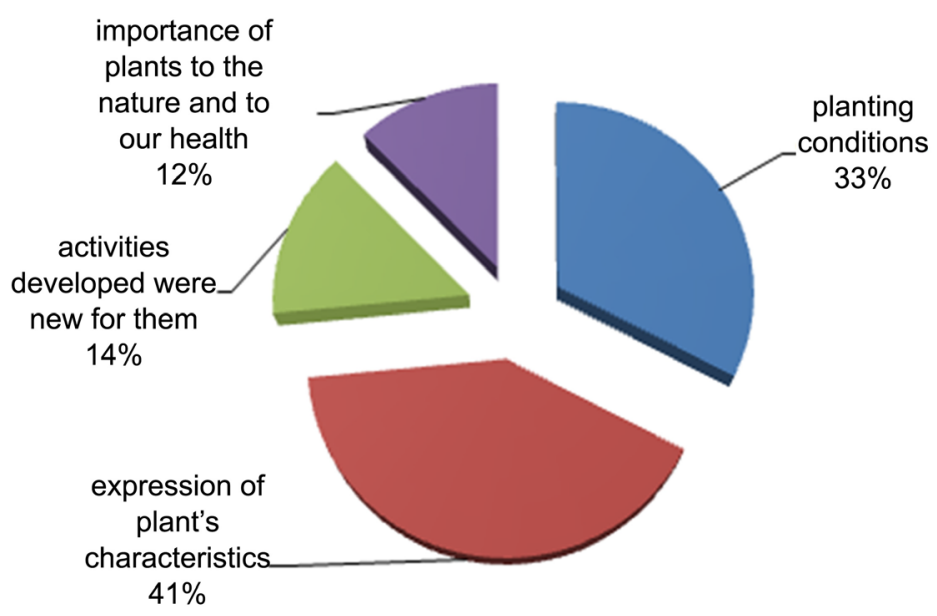

Figure 1. Contents described in the 26 texts written by children after observing the transformation of the stalks into seedlings (Day 2).

\subsection{Analyses of Plants}

In the last meeting (Day 3), the pots were removed by the children from the three greenhouses and the open box. They took measurements of the heights of the plants and counted the number of leaves on each of them. They recorded the results in their own tables. The means and standard deviations of these results are listed in Table 3.

Plant height results were significantly different when all results were compared: for the results between the soil types and between the results for each soil as a function of the $10 \%, 30 \%$ and $50 \%$ insolation rates (Table 4). However, the intensity of $100 \%$ did not produce significantly different heights in plants which grew in two types of soils.

Thus, we observed that both the soil types and the three insolation rates caused phenotypic plasticity of plant height (Table 3 and Table 4).

Subsequently, the children wrote a new report in which they described the characteristics of the plants. In these reports, the children showed that they understood the experiment performed with the Brazilian Boldo Brasileiro. All children reported that shading conditions favored plant growth. About $35 \%$ of the children additionally reported the positive influence of soil 2 on this difference. Some children (15\%) reported plant height values to exemplify their reports. No children mentioned the number of leaves per plant in the reports.

Through the reports, it was verified that children perceived that the shadow element favored the plant growth in height, mainly for the condition of $30 \%$ of sunlight intensity and in soil type 2 (vegetable compost + chicken manure). It was discussed with the children that the plants were searching for light and therefore they invested in height.

The drawings made by the children after planting Boldo Brasileiro (Day 1) and observed it (Day 3) reflected the activities experienced during the experiment carried out as exemplified in Figure 1 and Figure 2. There was no significant difference $(U=0.052 ;$ g.l. $=1 ; \mathrm{n}=8 ; p>0.05)$ between the drawings performed 
Table 3. Mean values of height $(\mathrm{cm})$ and leaves of Boldo Brasileiro (Plectranthus barbatus) that were cultivated in two types of soils and four degrees of solar intensity (\%).

\begin{tabular}{ccccc}
\hline \multirow{2}{*}{$\begin{array}{c}\text { Sunshine } \\
(\%)\end{array}$} & \multicolumn{2}{c}{ Soil type 1 } & \multicolumn{2}{c}{ Soil type 2 } \\
\cline { 2 - 5 } & Plant Height & Number of Leaves & Plant Height & Number of Leaves \\
\hline 10 & $40.72 \pm 0.47$ & $11.73 \pm 0.65$ & $47.36 \pm 1.57$ & $11.09 \pm 1.04$ \\
30 & $64.91 \pm 1.44$ & $17.0 \pm 0.05$ & $76.18 \pm 2.71$ & $16.45 \pm 0.52$ \\
50 & $38.27 \pm 1.68$ & $14.18 \pm 1.18$ & $52.82 \pm 3.06$ & $12.91 \pm 1.04$ \\
100 & $22.54 \pm 0.52$ & $9.82 \pm 1.17$ & $21.36 \pm 1.56$ & $9.73 \pm 3.13$ \\
\hline
\end{tabular}

Table 4. Analysis of variance of Boldo Brasileiro (Plectranthus barbatus) height results.

\begin{tabular}{lccccc}
\hline \multicolumn{1}{c}{ Comparison levels } & Statistic Test & g.l. & $\mathrm{n}$ & Statistic results & $p$ \\
\hline Among soils and solar intensity & & 7 & 10 & 84.51 & $\leq 0.005$ \\
Among the insolation rates for soil 1 & $H$ & 3 & 10 & 39.40 & $\leq 0.005$ \\
Among the insolation rates for soil 2 & & 3 & 10 & 40.33 & $\leq 0.005$ \\
\hline $\begin{array}{l}\text { Between soils for 10\% of insolation } \\
\text { Between soils for 30\% of insolation }\end{array}$ & & 1 & 10 & 4.11 & $\leq 0.005$ \\
Between soils for 50\% of insolation & & 1 & 10 & 4.03 & $\leq 0.005$ \\
Between soils for 100\% of insolation & & 1 & 10 & 4.30 & $\leq 0.005$ \\
\hline
\end{tabular}

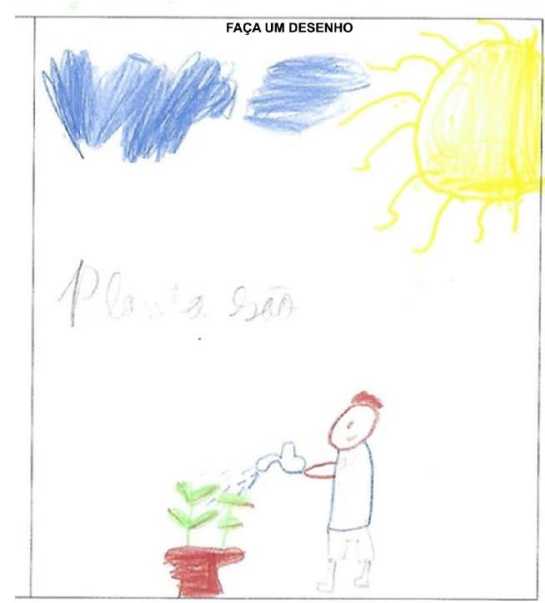

(A)

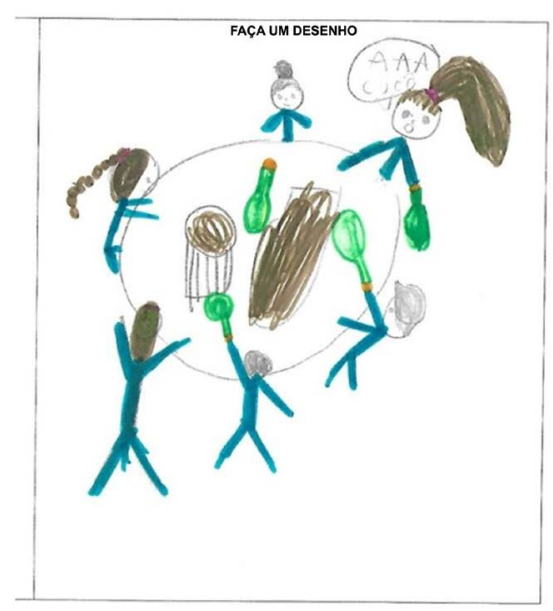

(B)

Figure 2. Drawings made by a boy (A) and a girl (B) after cutting of Boldo Brasileiro to be cultivated in two types of soil during 30 days (Day 1 ).

by the girls in relation to those executed by the boys regarding the presence of the elements (Figure 2 and Figure 3).

There was no significant difference $(U=0.052 ;$ g.l. $=1 ; \mathrm{n}=8 ; p>0.05)$ between the drawings performed by the girls in relation to those executed by the boys regarding the presence of the elements (Figure 4 and Figure 5).

The most frequent elements in the drawings were plants and pots (Figure 3 and Figure 5). The drawings created by the children on Day 3 illustrated the 


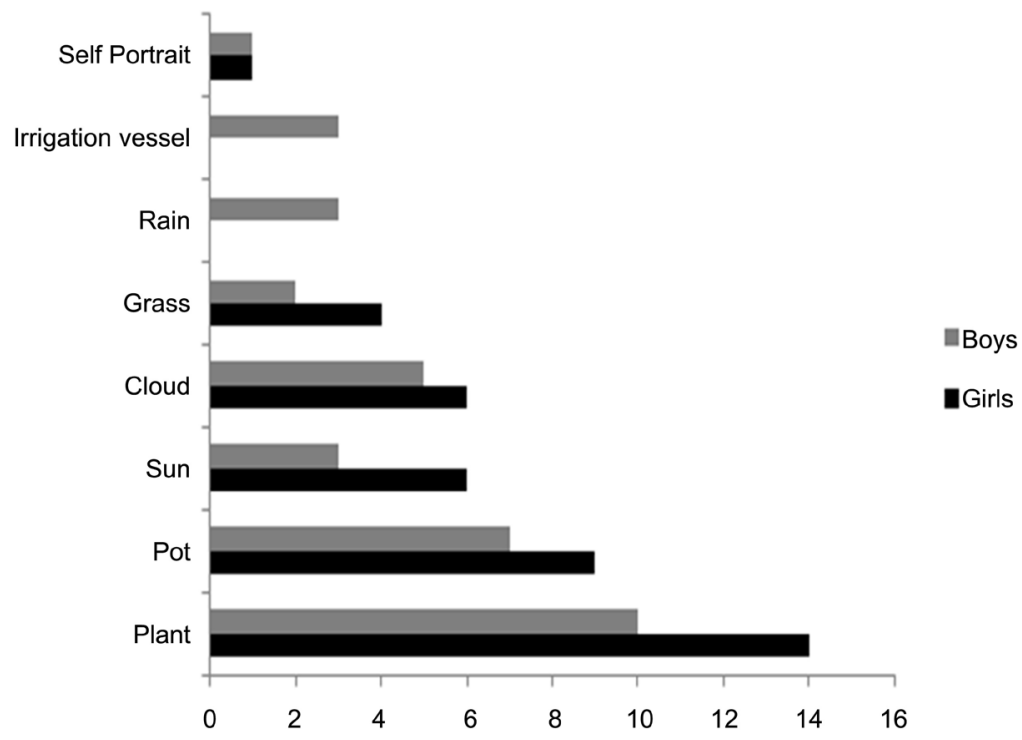

Figure 3. Presence of elements in the drawings made by the children that were made by the students after the planting of the Boldo Brasileiro (Day 1).

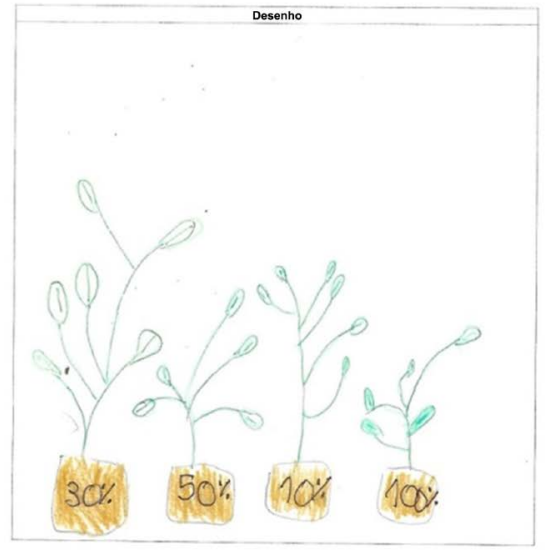

(A)

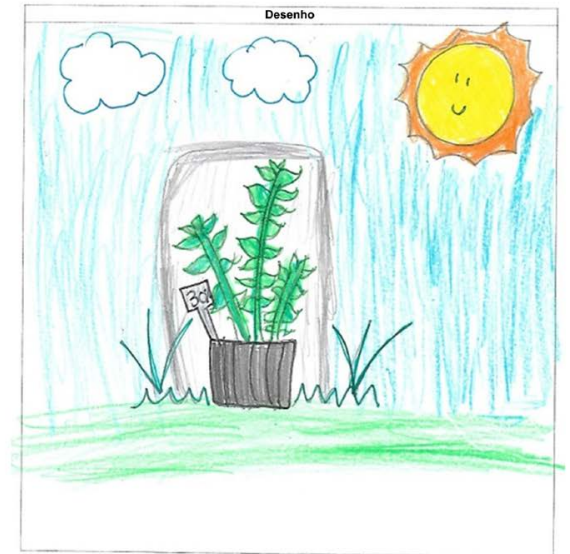

(B)

Figure 4. Drawings made by a boy (A) and a girl (B) after the evaluation of the expression of the phenotypic plasticity of the Boldo Brasileiro (Day 3 ).

greenhouses $(\mathrm{n}=3)$ and the phenotypic plasticity of plants for growth due to the sunshine intensity $(\mathrm{n}=5)$ (Figure 5).

The most frequent elements in the drawings were plants and pots (Figure 2). The drawings created by the children on Day 3 illustrated the greenhouses $(\mathrm{n}=$ 3 ) and the phenotypic plasticity of plants for growth due to the sunshine intensity $(\mathrm{n}=5)$ (Figure 3$)$.

Again, there were no significant differences ( $U=0.801$; g.l. $=1 ; \mathrm{n}=11 ; p>$ 0.05 ) between the drawings by the girls compared with those of the boys regarding the presence of the elements (Figure 3 ).

Moreover, no significant difference was observed for the presence of the elements between the drawings performed in the first stage (Figure 2) and the third stage (Figure 3 ) of the activities ( $H=1.19 ;$ g.l. $=3 ; \mathrm{n}=11 ; p>0.05)$. 


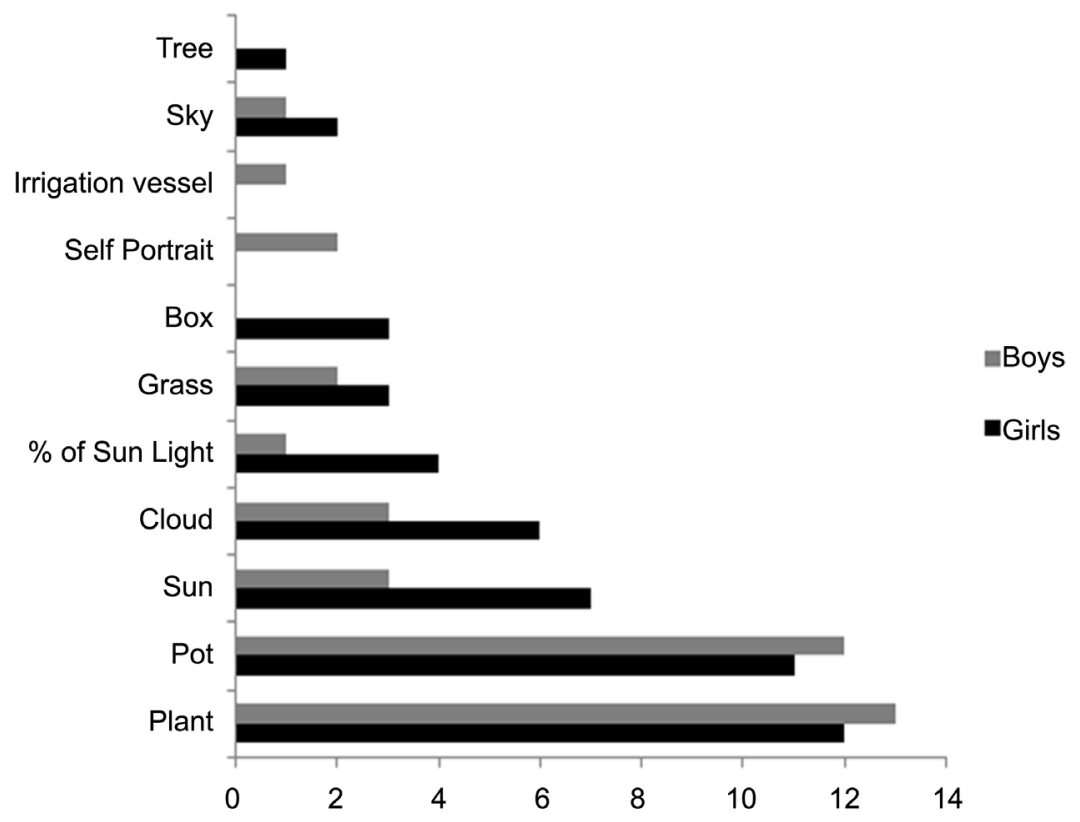

Figure 5. Presence of elements in the drawings made by the children that were made by the students after analyzing the expression of phenotypic plasticity of the Boldo Brasileiro (Day 3).

The students noticed that the greenhouse with $30 \%$ of light was the most satisfactory, because it had the amount of light and shade necessary for the growth of the plant. Some also observed differences in leaf size, as leaves at $30 \%$ light were larger compared to plants that were under other conditions.

Finally, a conversation was established to verify if the children understood the importance of plants to human health and nature. One child asked, "What did we learn from this?" We asked them to talk based on the statements of the children who wanted to give their testimonies. We observed that they knew how to describe the results by saying that light and soil caused the differential growth of plants.

\section{Discussion}

It was possible to identify the children's perception of plant importance to the nature and human health through the measurements they made on the plants, the observation of the experiment carried out, their questionnaire replies, their reports, their drawings, and a conversation that was established by the end of the activities to verify their understanding about the developed steps.

The children could observe the differences in morphology and smell characteristics between the two species of Plectranthus. They could perceive through the comparisons between the Boldo Mirim and the Boldo Brasileiro that each species has their own identity.

Moreover, the expression of Boldo Brasileiro phenotypic plasticity as a function of type of light and its intensity and nutrient concentration in soils demonstrated that plants can respond differently to environmental conditions. In this 
way, the children could experience the "critical conceptual step in the process of comprehension of the concept of living things: the grasping of the idea that plants are also living creatures" (Villarroel \& Infante, 2014: p. 124).

The growth patterns of Boldo Brasileiro corroborated with the results obtained by other studies that involved Boldo Mirim (Rosal et al., 2011; Lima, 2017; Sodré et al., 2018; Lima, 2019; Sodré et al., 2019). Thus, the experiments developed in the present study can be reproduced in other schools to approach aspects of environmental importance through the expression of phenotypic plasticity expressed by plants in response to environmental variables.

The strategies developed by the present study served to sharpen children's perceptions about aspects of the environment that are relevant to plant growth and at the same time facilitated recognition of the importance of flora to the nature.

As pointed out by Çil (2016: p. 366), "the integration of botany with chemistry and art is a good way to support children's positive attitudes towards plants, particularly for an instructional approach based on the integration of plants with various disciplines to support children's interest and enjoyment of plants".

When we pay attention to the activities of the children, we can see that they habitually like to draw and to ask and this is a privileged channel for expressing their ideas, wishes, emotions, in the way they read reality (Derdyk, 1989; Pereira, 2005).

The drawing seems to belong to the world of children. We could find in the drawings a fantastic or fanciful world where the child expresses himself. But is this expression only fantasy or an expression of its reality? How to understand children's drawing?

In this context, we analyze and verify that the elements figured in the drawings made by children such as pots and plants and elements of nature to evaluate how the students were involved with the activities performed. These analyses showed that the children, both girls and boys, were completely involved in the activities carried out by us in the school.

According to Derdyk (1989), the child's design provides the opportunity to perceive his world perception. Thus memory, imagination and observation meet past and future converging to the record of action in the present. The author also emphasizes that the drawing involves different mental operations, selecting and relating stimuli, symbolizing and representing, favoring the formation of concepts process.

The methods and techniques used in this study allowed us to verify that the most effective for this process was the observation about the children's speeches along with their drawings and essays. The students questioned the importance of each step of the present study asking "Why are we doing these activities?" However, as the children observed the results of the analyses they produced texts and arrived with conclusions expected by us.

Feeling, perceiving and thinking brings together the psychological knowledge necessary to understand the reality that surrounds us and the relationships we 
establish with the environment (Rodrigues et al., 2012). Our "most reliable" sense-vision-makes it possible to have numerous errors of perception (Rodrigues et al., 2012). Therefore, there are two types of perception: 1) the visual that brings together attitudes that do not consider the consequences, 2) the informational perception that involves the reflected actions.

In the discussion about the perception Rodrigues et al. (2012: p. 99) considered two authors views:

Forgus defined perception as "the process of extracting information," from the "reception, acquisition, assimilation, and use of knowledge," in which learning and thought are subordinated. For Morin (2000: p. 20), “[...] all perceptions are, at the same time, translations and brain reconstructions based on stimuli or signals captured and coded by the senses."

In this way, our "most reliable" sense-the vision-makes possible the innumerable errors of perception (Rodrigues et al., 2012: p. 99).

We observed that activities that involved the comparisons and measurements of plants that grow under different conditions were important for the development of environmental perception from an early age, as reported by other authors (Ribeiro, 2003; Marczwski, 2006; Çil, 2016; Fančovičová \& Prokop, 2011; Loureiro \& Dal-Farra, 2017; Dyg \& Wistoft, 2018).

Science education plays a very important role in educating children in promoting citizenship for the development of people as active citizens, consumers and responsible users of existing technology. In addition, science education is fundamental to awaken students' interest in scientific careers and thus increase the possibility for a country to have professionals capable of producing scientific and technological knowledge that could contribute to the economic and social development of the nation.

However, while on the one hand the importance of the democratization of scientific knowledge and the role of the school in the dissemination of scientific culture is recognized, on the other hand, research in science education has revealed a worrying situation regarding the teaching of this area, above all in the initial years of elementary school (Loureiro \& Dal-Farra, 2017).

Studies have shown that many teachers have difficulties in promoting a challenging condition, an innovative propensity to promote research and the construction of knowledge in science (Rosa et al., 2007; Ramos \& Rosa, 2008).

There are teachers who believe that students in the early years are not able to understand scientific knowledge. Others, although they recognize the importance of science, do not contemplate it in the classroom because they feel insecure to discuss and carry out a systematic work with the children (Rosa et al., 2007; Ramos \& Rosa, 2008).

In this sense, the educational work that we are developing in partnership with COLUNI's environmental education teachers has been creating opportunities for the undergraduate student to know how to develop strategies for science teaching, helping to demystify the belief that children do not have capacity to 
learn Science (Sodré et al., 2018; Lima, 2019).

The study conducted in COLUNI by Sodré et al. (2018) also involved the active participation of 2nd-year elementary school children in the planting process, in which they demonstrated enthusiasm and curiosity regarding the odor exhaled by the Boldo Mirim leaves and its growth in this mini-greenhouse illuminated by light bulbs which mimicked the sunlight.

The experiment that we carried out at COLUNI, contributed to the awakening of the children to the importance of plants for our food chain and health and helped them to understand the importance of environmental factors such as sunlight and soil nutrition, knowing that according to the conditions imposed, the plants can grow differently.

Thus, through activities, we observed that the children perceived the importance of environmental factors (soil and light) on the growth of plants. They were also able to experience scientific experiments and to focus on the theme of Plant Biology. In none of the drawings or essays were animals illustrated or mentioned except for the origin of soil components of bovine and chicken manure.

In addition, in the drawings made at the end of the activities was verified the presence of people as self-portraits and classmates and our team, but no child designed animals. The absence of animals in the drawings suggests that the theme Plant Biology has been well conceived by all children, and there is no "botanical blindness" which generally strikes the human species when observing nature.

Thus, the presence of natural elements and the absence of animals, indicate that the activities developed reached the children who understood the themes in question: difference between species, planting strategy, and the expression of phenotypic plasticity in living beings in response to the differences in environmental conditions.

The study of children's environmental perception is an essential tool for understanding behavior and planning actions that provide awareness and development of their ethical posture towards the environment they live in.

We consider that it is important and necessary to present, discuss and continually question children about environmental issues in elementary school, in order to explore the curiosity, interest and importance not only of science but also of the understanding of natural processes and preservation of the environment.

Conscientization and the valuation of the environment are essential for the formation of children's citizenship and their perceptions. Through the development of the perception about surroundings, it is possible to foster the construction of the critical spirit of children on the preservation of the environment.

\section{Conclusion}

The children realized the differences between the Boldo Brasileiro and Boldo Mirim related to leaf size, smell, and color. They observed that plant growth and the number of leaves of Boldo Brasileiro were related to the light source and the 
nutritional richness of the soil. Their drawings, reports, answers to the questionnaire applied, and their comments revealed that they were able to follow the comparative analyzes between the two plants and the experiment results.

Therefore, children had built up knowledge that can differentiate the plant species and also that these living beings respond to environmental variables, expressing phenotypic plasticity. The activities performed represented important tools to help the children to construct environmental perception and deconstruct the botanic blindness that affects most people since an early age.

\section{Acknowledgements}

We are grateful to Dr. Norman Arthur Ratcliffe of the Swansea University, UK, for the review and suggestions attributed to our article, the EMBRAPA's support to analyse the soils, and to the teacher Paula Rezende de Oliveira and the laboratory assistant Daniela Higuti Nogueira for supporting all the activities carried out in the Colégio Universitário Geraldo Reis (COLUNI) of Universidade Federal Fluminense.

\section{Conflicts of Interest}

The authors declare no conflicts of interest regarding the publication of this paper.

\section{References}

Adams, G. B. (2009). Environmental Crisis, Environmental Education and Sustainability. Revista Educação Ambiental em Ação, Number 30, Year VIII. http://www.revistaea.org/artigo.php?idartigo $=780$

Castro, H. C., Lima, N. R. W., Santos, C. S. G., Carlos, H. C., Mendes, A. B., Silva, G., Braga, G. L., Freitas, G., Feistel, M. A., Teixeira, P., \& Santos, R. (2014). BioFronteiras-UFF: Exploring an Educational Program that Spreads the Science Frontiers Themes. International Journal of Educational Management, 1, 1-5. http://mcmed.us/downloads/ijemar_2977179740.pdf

Çil, E. (2016). Instructional Integration of Disciplines for Promoting Children's Positive Attitudes towards Plants. Journal of Biological Education, 50, 366-383. https://doi.org/10.1080/00219266.2015.1117512

Costa, M. C. C. D. (2006). Popular Use and Pharmacological Actions of Plectranthus barbatus Andr. (Lamiaceae): Review of Published Works from 1970 to 2003. Revista Brasileira de Plantas Medicinais, 8, 81-88.

Derdyk, E. (1989). Ways of Thinking the Drawing. São Paulo: Scipione.

Dyg, P. M., \& Wistoft, K. (2018). Wellbeing in School Gardens-The Case of the Gardens for Bellies Food and Environmental Education Program. Environmental Education Research, 24, 1177-1191. https://doi.org/10.1080/13504622.2018.1434869

Fančovičová, J., \& Prokop, P. (2011). Plants Have a Chance: Outdoor Educational Programmes Alter Students' Knowledge and Attitudes towards Plants. Environmental Education Research, 17, 537-551. https://doi.org/10.1080/13504622.2010.545874

Futuyma, D. J. (2006). Evolution (2nd ed.). Sunderland, MA: Sinauer Associates. 
Lima, N. R. W. (2017). Boldo Mirim in Different Environments: Educational Practices, Sensory Stimuli and Knowledge Building. Niterói: ABDIn/PERSE.

https://www.researchgate.net/publication/325428232_Boldo_Mirim_em_Diferentes_A mbientes_Praticas_Educacionais_Estimulos_Sensoriais_e_Construcao_do_Conhecime $\underline{\text { nto }}$

Lima, N. R. W., Sodré, G. A., Lima, H. R. R., Paiva, S. R., Lobão, A. Q., \& Coutinho, A. J. (2017a). Phenotypic Plasticity. Revista de Ciência Elementar, 5, 1-7. https://doi.org/10.24927/rce2017.017

Lima, N. R. W., Sodré, G. A., Lima, H. R. R., Mancebo, S. S. S., Campos, L. V., Gibson, A., Souza, V., Couto, W., Giacomo, L., Narcizo, A., Lobão, A. Q., \& Delou, C. M. C. (2017b). The Efficacy of a Practical Activity in the Construction of Knowledge of the Concepts of Species and Phenotypic Plasticity using the Boldo Mirim (Plectranthus neochilus Schltr.). Creative Education, 8, 2036-2048.

http://file.scirp.org/pdf/CE_2017101714215128.pdf https://doi.org/10.4236/ce.2017.813138

Lima, N. R. W. (2019). Phenotypic Species and Plasticity of Plants: Teaching Strategies through the Practices of ProPET Biofronteiras of UFF(187 p.). Niterói: ABDIn/PERSE. https://www.researchgate.net/publication/331825092_Especies_e_plasticidade_fenotipi ca_de_plantas_estrategias_de_ensino_atraves_das_praticas_do_ProPET_Biofronteiras da_UFF

Loureiro, J. O., \& Dal-Farra, R. A. (2017). Botany and Environmental Education in Elementary School in Brazil: Articulating Knowledge, Values, and Procedures. Environmental Education Research, 24, 1655-1668. https://doi.org/10.1080/13504622.2017.1343280

Lukhoba, C. W., Simmonds, M. S. J., \& Paton, A. J. (2006). Plectranthus. A Review of Ethnobotanical Uses. Journal of Ethnopharmacology, 103, 1-24.

https://doi.org/10.1016/j.jep.2005.09.011

Marczwski, M. (2006). Evaluation of Environmental Perception in a Population of Elementary School Students in a Rural Municipal School: A Case Study. Master Dissertation, Porto Alegre: Universidade Federal do Rio Grande do Sul. https://lume.ufrgs.br/handle/10183/8617

Morin, E. (2000). The Seven Knowledge Needed to the Education of the Future. Brasília: Cortez Unesco.

Pasa, M. C. (2011). Local Knowledge and Folk Medicine: Ethnobotany in Cuiabá, Mato Grosso, Brazil. Boletimdo Museu Paraense Emilio Goeldi: Ciencias Humanas, 6, 179-196. https://doi.org/10.1590/S1981-81222011000100011 https://www.researchgate.net/publication/262669005_Local_knowledge_and_folk_med icine_ethnobotany_in_Cuiaba_Mato_Grosso_Brazil

Pereira, L. T. K. (2005). Children's Drawing and the Construction of Meaning: A Case Study.

http://atividadeparaeducacaoespecial.com/wp-content/uploads/2014/11/lais-krucken-p ereira.pdf

Ramos, L. B. C., \& Rosa, P. R. S. (2008). The Teaching of Science: Intrinsic and Extrinsic Factors That Limit the Accomplishment of Experimental Activities by the Teacher of the Initial Years of Elementary Education. Investigações em Ensino de Ciências, 13, 299-331. https://www.if.ufrgs.br/cref/ojs/index.php/ienci/article/view/444

Ribeiro, L. M. (2003). The Role of Social Representations in Environmental Education. Master Dissertation, Rio de Janeiro: Pontifícia Universidade Católica do Rio de Janeiro PUC. 
https://www.maxwell.vrac.puc-rio.br/colecao.php?strSecao=resultado\&nrSeq=4292@1

Rodrigues, M. L., Tadeu Fabrício Malheiros, T. F., Fernandes, V., \& Darós, T. D. (2012). Environmental Perception as an Instrument of Support in the Management and Formulation of Environmental Public Policies. Saúde e Sociedade, 21, 96-110.

https://doi.org/10.1590/S0104-12902012000700009

http://www.scielo.br/pdf/sausoc/v21s3/09.pdf

Rosa, C. W., Rosa, Á. B. da., \& Pecatti, C. (2007). Experimental Activities in the Initial Series: Report of an Investigation. Revista Electrónica de Enseñanza de las Ciencias, 6, 263-274. http://reec.uvigo.es/volumenes/volumen6/ART3_Vol6_N2.pdf

Rosal, L. F. (2008). Production of Biomass, Essential Oil and Foliar Physiological and Anatomical Characteristics of Plectranthus neochilus Schlechter Due to Organic Fertilization, Color Meshes and Plant Age (134 p.). Tese de Doutorado, Lavras: Universidade Federalde Lavras.

http://repositorio.ufla.br/bitstream/1/3283/1/TESE_Produ\%C3\%A7\%C3\%A3o\%20de\% 20biomassa\%2C\%20\%C3\%B3leo\%20essencial\%20e\%20caracter\%C3\%ADsticas\%20fisii ol\%C3\%B3gicas\%20anat\%C3\%B4micas\%20foliares\%20de\%20Plectranthus\%20neochil us\%20Schlechter\%20em\%20fun\%C3\%A7\%C3\%A3o\%20da\%20aduba\%C3\%A7\%C3\%A 3o\%20org\%C3\%A2nica\%2C\%20malhas\%20coloridas.pdf

Rosal, L. F., Pinto, J. E. B., Bertolucci, S. K. V., Brant, R. S., Nicolau, E. S., \& Péricles Barreto Alves, P. B. (2011). Vegetable Production and Small Boldo Essential Oil Due to Sources of Organic Fertilizers. Revista Ceres, 58, 670-678.

https://doi.org/10.1590/S0034-737X2011000500020

Salatino, A., \& Buckeridge, M. (2016). But What Does Botany Know of. Estudos Avançados, 30, 177-196. https://doi.org/10.1590/S0103-40142016.30870011

Scheiner, S. (1993). Genetics and Evolution of Phenotypic Plasticity. Annual Review of Ecology and Systematics, 24, 35-68. https://doi.org/10.1146/annurev.es.24.110193.000343 https://www.annualreviews.org/doi/abs/10.1146/annurev.es.24.110193.000343

Sodré, A. G., Ferah, P., Lima, R. R. H., Campos, V. L., Delou, C. M. C., \& Lima, N. R. W. (2018). Phenotypic Plasticity of Boldo Mirim (Plectranthus neochilus Schlechter) within Rich of Children from Second Degree of Elementary School. Creative Education, 9, 1359-1376. https://doi.org/10.4236/ce.2018.99101 https://www.scirp.org/journal/PaperInformation.aspx?PaperID $=86098$

Sodré, A. G., Ferah, P., Lima, R. R. H., Perdigão, L. T., \& Lima, N. R. W. (2019). Construction of Biological Concepts of Species and Phenotypic Plasticity Based on a Theoretical-Practical Class with Two Species of Boldo Plectrantus neochilus and P. barbatus. Revista Ciências \& Idéias, 10, 118-136. https://doi.org/10.22407/2019.v10i1.913 https://revistascientificas.ifrj.edu.br/revista/index.php/reci/article/view/913/654

Teixeira, P. C., Donagemma, G. K., Fontana, A., \& Teixeira, W. G. (2017). Manual of Soil Analysis Methods (3rd ed., p. 573). Embrapa Solos-Livro técnico (INFOTECA-E). https://www.infoteca.cnptia.embrapa.br/handle/doc/1085209

Villarroel, J. D., \& Infante, G. (2014). Early Understanding of the Concept of Living Things: An Examination of Young Children's Drawings of Plant Life. Journal of Biological Education, 48, 119-126. https://doi.org/10.1080/00219266.2013.837406

Wandersee, J., \& Schussler, E. (1999). Preventing Plant Blindness. The American Biology Teacher, 61, 82-86. https://abt.ucpress.edu/content/61/2/82 https://doi.org/10.2307/4450624 